\title{
PENGARUH PENAMBAHAN BUAH NAGA MERAH (Hylocereus polyrhizus) TERHADAP MUTU PERMEN KARAMEL SUSU
}

\section{EFFECT OF ADDITION OF RED DRAGON FRUIT (Hylocereus polyrhizus) TO QUALITY OF MILK CARAMEL CANDY}

\author{
Marlina 1), Muhammad Wijaya 2), Kadirman ${ }^{3)}$ \\ 1Alumni Program Studi Pendidikan Teknologi Pertanian \\ ${ }^{2}$ dan ${ }^{3}$ Dosen PTP FT UNM \\ marlinaptp018@gmail.com
}

\begin{abstract}
ABSTRAK
Penelitian ini bertujuan untuk mengetahui pengaruh penambahan buah naga merah terhadap kandungan kimia dan hedonik susu karamel. Penelitian ini menggunakan metode penambahan $20 \%, 30 \%$, dan $40 \%$ bubur buah naga merah untuk permen susu karamel dengan waktu memasak 2 jam pada $80^{\circ} \mathrm{C}$. Penelitian ini merupakan penelitian kuantitatif (eksperimen) menggunakan Rancangan Acak Lengkap (RAL) dengan 4 perlakuan, masing-masing kontrol, $20 \%, 30 \%$, dan $40 \%$ dengan 3 ulangan. Data penelitian diperoleh dari hasil pengujian kimia (kadar air, kadar abu, serat, gula reduksi, dan antioksidan) dan organoleptik (warna, rasa, aroma, dan tekstur), data dianalisis menggunakan analisis varian (ANOVA) dan dilanjutkan dengan tes DRMT (Duncan) pada tingkat kepercayaan 95\%. Hasil penelitian menunjukkan bahwa penambahan bubur buah naga merah memiliki efek pada permen susu karamel, penelitian terbaik pada pembuatan susu karamel adalah penambahan $40 \%$ bubur buah naga merah dengan karakteristik kadar air 3,54\%, kadar abu 1,98\%., Kandungan serat 1,48\%, kadar gula menurun $2,18 \%$, kadar antioksidan $53,77 \%$, nilai warna favorit 4,10, nilai aroma favorit 3,52, rasa 3,83, dan nilai tekstur favorit 3,23.
\end{abstract}

Kata Kunci: Buah Naga Merah, Bubur, Kandungan kimia, dan Karamel Susu

\section{ABSTRACT}

This study aims to determine the effect of adding red dragon fruit to the chemical and hedonic content of caramel milk. This study used a method of adding $20 \%, 30 \%$, and $40 \%$ red dragon fruit pulp for caramel milk candy with a cooking time of 2 hours at $80^{\circ} \mathrm{C}$. This research is a quantitative study (experiment) using a completely randomized design (CRD) with 4 treatments, each control, $20 \%, 30 \%$, and $40 \%$ with 3 replications. The research data was obtained from the results of chemical testing (moisture content, ash content, fiber, reduction sugar, and antioxidants) and organoleptic (color, taste, aroma, and texture), data were analyzed using analysis of variance (ANOVA) and continued with DRMT test (Duncan) at a 95\% confidence level. The results showed that the addition of red dragon fruit pulp had an effect on caramel milk candy, the best research on the manufacture of caramel milk was the addition of $40 \%$ red dragon fruit pulp with characteristics of $3.54 \%$ moisture content, $1.98 \%$ ash content, $1.48 \%$ fiber content, decreased sugar content $2.18 \%$, antioxidant content $53.77 \%$, favorite color value 4.10 , favorite aroma value 3.52, flavor 3.83, and favorite texture value 3.23.

Key word: Red Dragon Fruit, Porridge, Chemical Content, and Milk Caramel 


\section{PENDAHULUAN}

Susu segar merupakan bahan makanan yang bergizi tinggi karena mengandung zat-zat makanan yang lengkap dan seimbang seperti protein, lemak, karbohidrat, mineral, dan vitamin yang sangat dibutuhkan oleh manusia. Nilai gizinya yang tinggi juga menyebabkan susu merupakan medium yang sangat disukai oleh mikroorganisme untuk pertumbuhan dan perkembangannya sehingga dalam waktu yang sangat singkat susu menjadi tidak layak dikomsumsi bila tidak ditangani secara benar. Proses pengolahan susu bertujuan untuk memperoleh produk susu yang beraneka ragam, berkualitas tinggi, tahan simpan, mempermudahpemasaran dan transportasi, sekaligus meningkatkan nilai tukar dan daya guna bahan mentahnya. Proses pengolahan susu selalu berkembang sejalan dengan berkembangnya ilmu di bidang teknologi pangan, dengan demikian semakin lama akan semakin banyak jenis produk susu yang dikenal.

Produk olahan susu yang telah dikenal dengan proses pembuatan yang mudah adalah permen karamel susu. Permen karamel susu berbahan dasar susu murni dan gula, produk permen dihasilkan dari proses karamelisasi dan reaksi Maillard yang diakibatkan adanya reaksi antara gula reduksi dan protein sehingga menghasilkan permen yang beraroma karamel dan berwarna coklat. Produk olahan susu sangat penting mengingat masyarakat sangat menggemari berbagai produk diversifikasi yang inovatif dan menyehatkan. Produk olahan susu yang inovatif dan menyehatkan khususnya produk olahan permen karamel susu dapat dibuat dengan menambahkan bahan-bahan alami seperti buah-buahan yang dapat memberikan flavor serta warna yang menarik pada permen karamel susu yang dihasilkan.

Salah satu sumberdaya alam yang belum dimanfaatkan secara optimal adalah buah naga merah (Hylocereus polyrhizus) atau biasa disebut dengan dragon fruit. Buah naga merah saat ini merupakan buah yang sudah banyak ditemukan di Indonesia. Gede, dkk (2017) melaporkan produksi buah naga pada tahun 2010 sebanyak $4.274 \mathrm{~kg}$, meningkat menjadi $4.720 \mathrm{~kg}$ pada tahun 2011. Terdapat empat jenis buah naga yang dikembangkan, yaitu buah naga daging putih ( $H$. undatus), buah naga daging merah ( $H$. polyrhizus), buah naga daging super merah $(H$. costaricensis), dan buah naga kulit kuning daging putih (Selenicereus megalanthus).

Buah naga mempunyai kandungan zat bioaktif yang bermanfaat bagi tubuh diantaranya antioksidan (asam askorbat, betakaroten, dan antosianin) dan mengandung serat pangan dalam bentuk pektin. Selain itu, buah naga mengandung beberapa mineral seperti kalsium, besi, dan lain-lain. Vitamin yang terdapat di dalam buah naga antara lain vitamin B1, vitamin B2, vitamin B3, dan vitamin C (Wahyuni, 2011). Buah naga masih jarang ditemukan dalam bentuk produk, kebanyakan buah naga dikomsumsi secara langsung. Buah naga mengandung kadar air yang tinggi sehingga bersifat mudah rusak dan tidak dapat disimpan pada jangka waktu yang lama. Selain itu, buah naga memiliki kandungan antosianin dan memiliki pigmen yang dikenal dengan nama betalain.I

Betalain merupakan pigmen yang mengandung nitrogen dan terdinitrogen dari betasianin yang memberi warna merahviolet sehingga dapat dijadikan sebagai pewarna alami (Afriandi, 2018). Salah satu 
cara pengolahan yang dapat dilakukan yaitu proses pengolahan permen karamel susu dengan penambahan buah naga merah sebagai alternatif bahan pemberi cita rasa (flavor), pewarna alami dan memiliki nilai tambah bagi kesehatan. Oleh karena itu, penelitian yang berjudul " Pengaruh Penambahan Buah Naga Merah (Hylocereus polyrhizus) Terhadap Mutu Permen Karamel Susu" dilakukan.

\section{TUJUAN PENELITIAN}

berikut:

Penelitian ini bertujuan sebagai

1. Untuk mengetahui pengaruh penambahan buah naga merah $(H$. polyrhizus) terhadap kandungan kimia permen karamel susu.

2. Untuk mengetahui pengaruh penambahan buah naga merah $(H$. polyrhizus) terhadap mutu hedonik permen karamel susu.

\section{METODE PENELITIAN}

Jenis penelitian ini adalah penelitian eksperimen yang memformulasikan susu cair dan penambahan daging buah naga merah dalam pembuatan karamel susu.

Rancangan percobaan yang digunakan dalam penelitian ini adalah rancangan acak lengkap ( $R A L$ ) dimana dilakukan empat perlakuan dengan konsentrasi penambahan bubur buah naga merah yaitu 0\%, 20\%, 30\%, dan 40\% dilakukan pengulangan sebanyak tiga kali sehingga jumlah yang diamati adalah 12 sampel percobaan.

Penelitian ini terdiri dari dua tahapan yaitu tahap persiapan dan tahap pelaksanaan.

\section{Tahap persiapan}

Alat yang digunakan dalam pembuatan karamel susu dengan penambahan bubur buah naga merah disiapkan dan dikondisikan dengan baik. Semua bahan yang digunakan yaitu susu sapi, buah naga merah, dan gula pasir, ditimbang dan diukur sesuai dengan komposisi yang akan digunakan dalam penelitian ini.

\section{Tahap Pelaksanaan}

Pembuatan karamel susu dengan penambahan bubur buah naga merah yaitu sebagai berikut:

a. Pengolahan buah naga merah menjadi bubur

1) Buah naga merah dicuci hingga bersih

2) Kemudian buah naga dipisahkan dari kulitnya

3) Setelah itu, buah naga merah kemudian dipotong kecil-kecil dan dihaluskan menggunkan blender

4) Buah naga merah yang telah dihancurkan kemudian ditimbang kembali sesuai dengan perlakuan penambahan yaitu konsentrasi $20 \%$, $30 \%$, dan $40 \%$

b. Pengolahan karamel susu

1) Susu $1000 \mathrm{ml}$ dipanaskan dalam wajan dengan suhu kurang lebih $80^{\circ} \mathrm{C}$ tunggu sampai volume susu berkurang $1 / 2$ dari volume awal dengan waktu pemasakan 1 jam.

2) Setelah susu yang dipanaskan berkurang $1 / 2$ dari volume awalnya, pada waktu 1 jam tersebut gula pasir sebanyak $15 \%$ dan gula cair (fruktosa) sebanyak 5\% dimasukkan dan diaduk hingga homogen

3) Susu yang telah diberi gula pasir dan gula cair (fruktosa) tetap dipanaskan 
dengan suhu $80^{\circ} \mathrm{C}$ sampai mengental dengan lama pemasakan 30 menit.

4) Pada menit ke 90, bubur buah naga merah ditambahkan ke dalam adonan susu yang telah diberi gula, adonan diaduk hingga homegen.

5) Adonan yang telah homogen dipanaskan dengan $80^{\circ} \mathrm{C}$ sambil diaduk terus hingga adonan mengental dan matang, waktu pemasakan selama 30 menit.

6) Untuk mengetahui apakah adonan karamel susu telah matang dapat dilakukan pengujian berikut:

(a) Adonan karamel susus yang sedang dimasak diambil sedikit dengan sendok makan, lalu tuangkan kedalam gelas yang berisi air dingin.

(b)Apabila adonan membentuk bulatan atau gumpalan utuh dalam air dingin dan tetap utuh setelah dikeluarkan dari air dingin, maka adonan tersebut dianggap sudah matang.

7) Karamel susu yang telah matang kemudian dituang ke dalam loyang tunggu sampai dingin dan mengeras, setelah itu cetak dan kemas dengan mengunakan kemasan plastik.
Penelitian ini dilaksanakan di Laboratorium Pendidikan Teknologi Pertanian, fakultas teknik Universitas Negeri Makassar dan Laboratorium Kimia Makanan Ternak Jurusan Nutrisi dan Makanan Ternak Fakultas Peternakan Universitas Hasanuddin. Penelitian dilaksanakan pada bulan November 2016 sampai dengan Januari 2017.

Data analisis penelitian yang telah diperoleh selanjutnya dianalisis statistika menggunakan program SPSS (versi 22). Uji persyaratan analisis yang menggunakan uji homogenitas dan uji normalitas pada karakteristik fisikokimia menggunakan uji kolmogrov-Semirnov dan Shapiro-Wilk. Hasil uji menunjukkan bahwa data penelitian terdistribusi normal dan homogeny, maka dilakukan analisis sidik ragam (ANOVA). Jika terdapat beda nyata diantara perlakuan maka dilanjutkan dengan uji lanjut Duncan dengan taraf kepercayaan $95 \%$.

\section{HASIL DAN PEMBAHASAN}

Kadar Air

Hasil pengujian analisis kadar air permen karamel susu dapat dilihat pada Gambar 1.

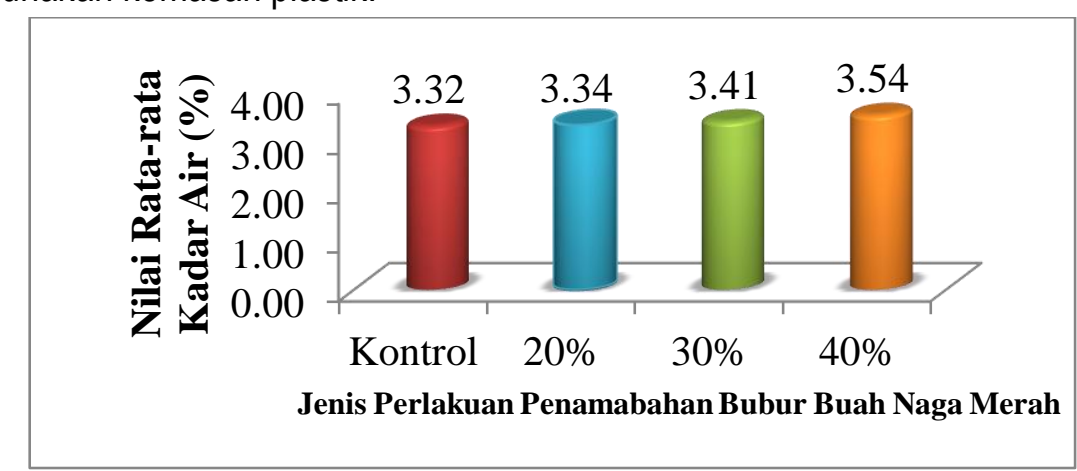

Gambar 1.Hasil Uji Kadar Air Karamel Susu

Hasil uji lanjut Duncan kadar air permen karamel susu buah naga merah menunjukkan bahwa kadar air permen karamel susu perlakuan tanpa penambahan bubur buah naga merah atau kontrol dan penambahan bubur buah naga merah $20 \%$ 
tidak memiliki perbedaan nyata sedangkan kadar air permen karamel susu perlakuan penambahan bubur buah naga merah 30\% dan $40 \%$ menunjukkan perbedaan nyata dengan kontrol. Permen karamel susu perlakuan penambahan bubur buah naga merah 40\% menghasilkan kadar air tertinggi. Hal ini dipengaruhi oleh konsentrasi penambahan bubur buah naga merah. Semakin tinggi konsentrasi penambahan bubur buah naga merah pada pengolahan permen karamel susu, maka akan semakin berpengaruh terhadap kadar air permen karamel susu, hal tersebut terutama disebabkan oleh tingginya kadar air buah naga merah yang mendominasi buahnya. Menurut Hardita, (2015) kandungan air dalam 100 gram buah naga merah yaitu 80-90 g.

Kadar air permen karamel susu perlakuan tanpa penambahan bubur buah naga merah atau kontrol dan permen karamel susu perlakuan penambahan bubur buah naga merah 20\% memiliki kadar air terendah. Hal ini disebabkan selama proses pemasakan terjadi penguapan air oleh proses pemanasan. Menurut Winarno (2004) kandungan air menguap pada proses karamelisasi, dimana jika larutan sukrosa dipanaskan, maka konsentrasinya akan meningkat, demikian juga titik didihnya, keadaan ini akan terus menerus berlangsung sehingga seluruh air pada permen akan menguap.

Hasil penelitian kadar air pada permen karamel susu menunjukkan nilai rata-rata kadar air permen karamel susu perlakuan $0 \%, 20 \%$, dan 30\% masih memenuhi standar mutu nasional (SNI) karamel susu yaitu maksimal 3,5\%.

\section{Kadar Abu}

Hasil pengujian kadar abu permen karamel susu buah naga dapat dilihat pada Gambar 2.

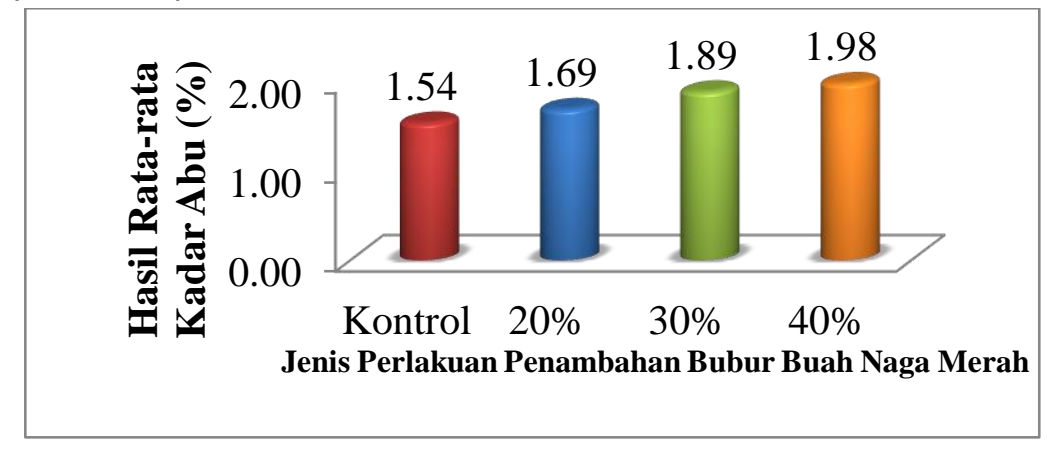

Gambar 2. Hasil Uji Kimia Kadar Abu

Hasil uji lanjut Duncan kadar abu permen karamel susu buah naga merah menunjukkan bahwa perlakuan penambahan bubur buah naga merah memberikan pengaruh terhadap kadar abu permen karamel susu. Permen karamel susu perlakuan penambahan bubur buah naga merah $30 \%$ dan $40 \%$ bubur buah naga merah memiliki kadar abu tertinggi dibandingkan perlakuan lainnya. Perlakuan penambahan bubur buah naga merah memberikan pengaruh terhadap kadar abu permen karamel susu. Permen karamel susu yang memiliki kadar abu tertinggi dipengaruhi oleh kandungan mineral anorganik yang terdapat pada buah naga merah. Menurut Hardita (2015) buah naga memiliki kandungan mineral berupa kalsium, posfor,dan magnesium. 
Permen karamel susu perlakuan tanpa penambahan bubur buah naga merah atau kontrol,memiliki kadar abur terendah. Kadar abu permen karamel susu pelakuan kontrol berasal dari kandungan mineral yang terdapat pada susu yaitu 7 elemen makro yang terdiri atas kalsium, fosfor, kalium, natrium, klor, magnesium, dan sulfur. Mineral mikro yaitu cobalt, tembaga, yodium, besi, mangan, molybdenum, selenium, dan seng (Budiyanto, 2002). Penentuan kadar abu bertujuan untuk mengetahui mutu suatu bahan pangan, hasil penelitian kadar abu permen karamel susu menunjukkan nilai rata-rata kadar abu dengan rentang $1.54 \%-1.98 \%$ telah memenuhi standar mutu (SNI) permen karamel yaitu maksimal $2.0 \%$.

\section{Serat}

Hasil uji kimia kadar serat permen karamel susu dengan penambahan bubur buah naga merah dapat dilihat pada Gambar 3.

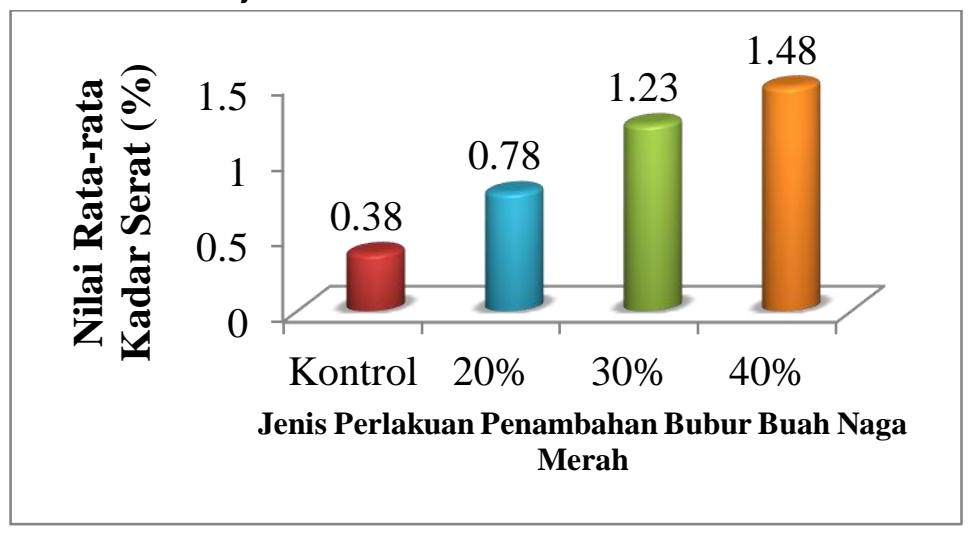

\section{Gambar 3. Hasil Uji Serat Permen Karemel Susu}

Data hasil penelitian kadar serat permen karamel susu buah naga merah menunjukkan bahwa setiap perlakuan memiliki perebedaan nyata. Pengujian menunjukkan permen karamel susu penambahan bubur buah naga merah $40 \%$ memiliki kandungan serat yang tinggi. Penambahan konsentrasi bubur buah naga merah sangat berpengaruh terhadap kandungan serat permen karamel susu yang dihasilkan. Menurut Hardita (2015) kandungan serat buah naga merah tiap 100 gram yakni 0,71gram. Menurut Sriwahyuni, dkk (2017) kandungan serat pangan mencakup polisakarida berfungsi sebagai penguat tekstur (selulosa, hemiselulosa, pectin, dan lignin) dan sebagai sumber

\section{Gula Reduksi}

Hasil uji kadar gula reduksi disajikan pada Gambar 4. energi (pati, desktrin, glikogen, fruktan). Polisakarida penguat tekstur ini tidak dapat dicerna oleh tubuh, tetapi merupakan seratserat (dietary fiber) yang dapat menstimulasi enzim-enzim pencernaan.

Kadar serat terendah diperoleh dari permen karamel susu perlakuan tanpa penambahan bubur buah naga merah atau kontrol. Hal ini dipengaruh oleh kandungan gula pasir yaitu karbohidrat, yang dikelompokkan menjadi oligosakarida berupa sukrosa dan laktosa. Serat makanan adalah komponen bahan makanan yang penting bagi kesehatan tubuh kita. Serat pangan banyak terdapat dalam sayuran, buah, bulir utuh, biji-bijian dan polongpolongan. 


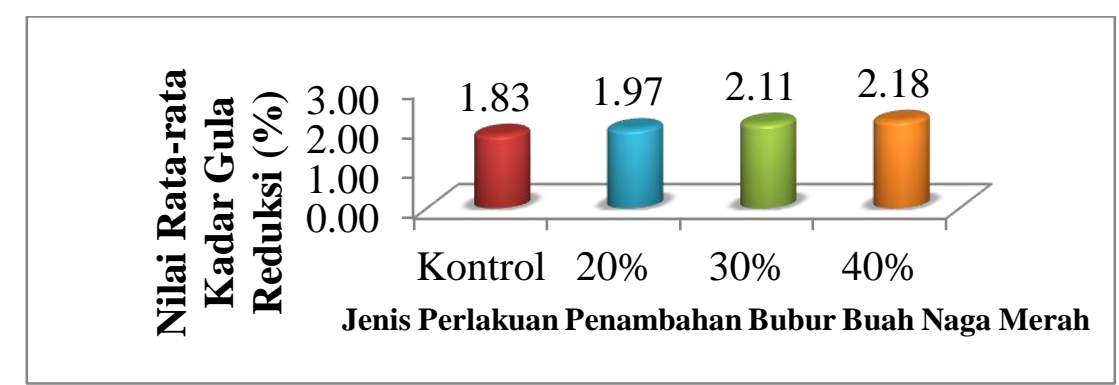

Gambar 4. Hasil Uji Gula Reduksi Karamel Susu

Gula reduksi permen karamel susu penambahan bubur buah naga merah memiliki perbedaan nyata dengan permen karamel susu tanpa penambahan bubur buah naga merah atau kontrol. Hasil uji Duncan gula reduksi permen karamel susu buah naga merah menunjukkan bahwa permen karamel susu perlakuan penambahan $30 \%$ dan $40 \%$ bubur buah naga merah memiliki kadar gula reduksi yang tertinggi dibandingkan perlakuan lainnya. Hasil penelitian menunjukkan penambahan bubur buah naga merah berpengaruh terhadap kadar gula reduksi permen karamel susu. Kadar gula reduksi buah naga merah menjadi salah satu faktor terjadinya peningkatan kadar gula reduksi permen karamel susu yang di hasilkan. Menurut Wahyuni (2011) peningkatan kadar gula reduksi dipengaruhi oleh konsentrasi penambahan bubur buah naga merah, dimana buah naga merah mengandung gula 13-18 briks

Kadar gula reduksi terendah permen karamel susu diperoleh dari perlakuan tanpa adanya penambahan bubur buah naga merah atau kontrol, meskipun terbilang rendah, gula reduksi yang dihasilkan oleh permen karamel susu tanpa penambahan bubur buah naga merah masih sesuai dengan standar nasional (SNI) permen karamel susu yaitu 2.2\%. Gula reduksi permen karamel susu tanpa penambahan bubur buah naga merah diperoleh dari bahan dasar yang digunakan yaitu susu (laktosa), gula pasir (sukrosa) dan gula cair (fruktosa). Inversi sukrosa menghasikan gula invert atau gula reduksi (glukosa dan fruktosa) dalam proses karamelisasi dan reaksi mailard. Gula invert akan mengkatalisis proses inversi sehingga kehilangan gula akan berjalan dengan cepat (Winarno, 2004)

Gula pereduksi merupakan salah satu parameter penting dalam persyaratan mutu permen. Kadar gula reduksi permen ditentukan oleh komposisi rasio sukrosa dan sirup glukosa. Semakin banyak sukrosa yang mengalami inversi menjadi glukosa dan fruktosa maka gula reduksi semakin meningkat. Budiyanto (2002) mengemukakan bahwa sukrosa yang dilarutkan dalam air yang dipanaskan, maka sebagian sukrosa akan terurai menjadi glukosa dan fruktosa yang disebut gula invert.

\section{Antioksidan}

Antioksidan karamel susu dengan penambahan bubur buah naga merah dapat dilihat pada Gambar 5. 


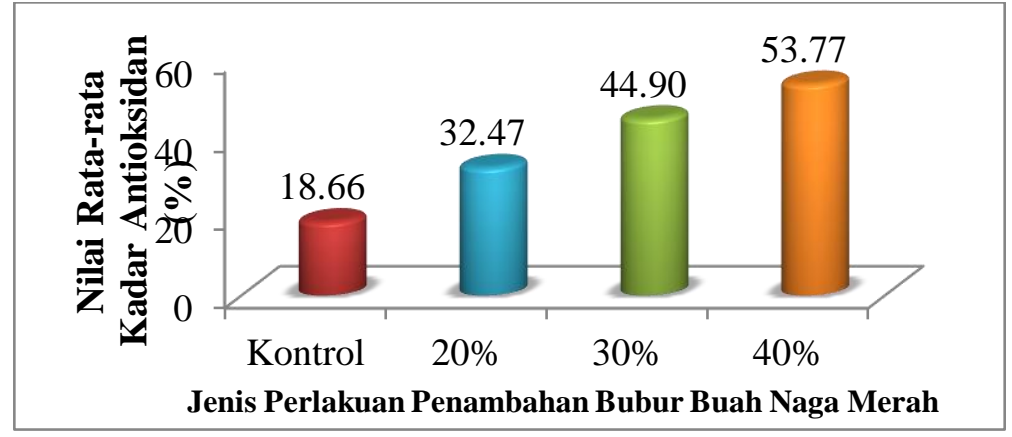

Gambar. 5. Hasil Uji Antioksdan Karemal Susu

Kadar antioksidan permen karamel susu buah naga merah menunjukkan bahwa setiap perlakuan memiliki perebedaan nyata. Hasil analisis data permen karamel susu menunjukkan penambahan bubur buah naga merah berpengaruh terhadap peningkatan kadar antioksidan permen karamel susu. Permen karamel susu dengan kandungan antioksidan tertinggi diperoleh dari perlakuan penambahan $40 \%$ bubur buah naga merah. Menurut Hardita (2015) buah naga merah memiliki kandungan antioksidan yang tinggi yang bermanfaat bagi tubuh seperti asam askorbat, betakaroten dan antosianin. Antioksidan tertinggi dipengaruhi oleh sedikitnya kerusakan antioksidan dalam proses pemasakan. Proses pemanasan juga merupakan faktor terbesar yang menyebabkan kerusakan antioksidan. Proses pemanasan terbaik untuk mencegah kerusakan antioksidan adalah pengolahan pada suhu tinggi, tetapi dalam jangka waktu yang sangat pendek High Temperature Short Time (HTST).

Permen karamel susu dengan kandungan antioksidan terendah diperoleh dari perlakuan tanpa adanya penambahan bubur buah naga merah atau kontrol, meskipun tanpa penambahan bubur buah naga merah, permen karamel susu perlakuan kontrol masih memiliki kandungan antioksidan yang diperoleh dari bahan dasar pembuatan permen karamel susu yaitu vitamin $C$ dan vitamin $A$ yang terkandung dalam susu sapi. Permen karamel susu perlakuan tanpa penambahan bubur buah naga merah memiliki antioksidan yang rendah dikarenakan senyawa-senyawa antioksidan yang terkandung dalam susu banyak mengalami kerusakan akibat lamanya pemasakan dan suhu yang digunakan.

\section{Warna}

Hasil uji organoleptik warna permen karamel susu dapat dilihat pada Gambar 6.

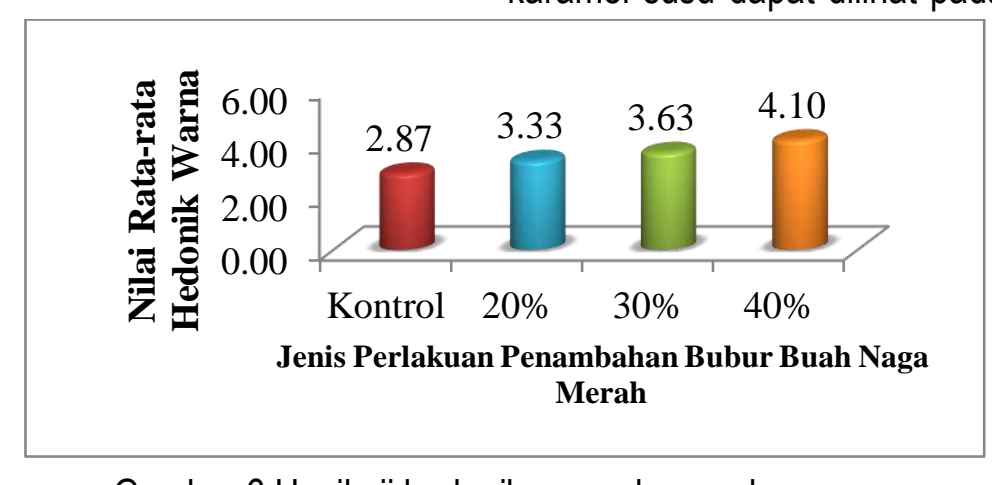

Gambar 6.Hasil uji hedonik warna karamel susu 
Data Pengujian warna permen karamel susu buah naga merah menunjukkan bahwa permen karamel susu perlakuan penambahan $0 \%, 20 \%, 30 \%$, dan $40 \%$ bubur buah naga merah memiliki perbedaan nyata. Hal tersebut menunjukkan bahwa penambahan bubur buah naga merah memberikan pengaruh terhadap tingkat kesukaan warna permen karamel susu. Permen karamel susu perlakuan penambahan bubur buah naga merah 40\% merupakan permen karamel susu yang memiliki warna yang paling disukai oleh panelis. Warna permen karamel susu perlakuan penambahan bubur buah naga merah 40\% yaitu merah cerah. Cindy, dkk (2017) buah naga merah memiliki kandungan antoksidan berupa antosianin dan memiliki pigmen yang dikenal dengan nama betalain. Betalain merupakan pigmen yang mengandung nitrogen dan terdinitrogeni dari betasianin yang memberi warna merah-violet. Semakin banyak konsentrasi bubur buah naga merah yang ditambahkan maka kadar antioksidan akan tinggi dan menghasilkan warna permen karamel susu menjadi semakin berwarna merah cerah.

Warna permen karamel susu yang tidak disukai panelis diperoleh dari perlakuan tanpa adanya penambahan bubur buah naga merah. Warna permen karamel yang dihasilkan tidak menarik dibandingkan permen karamel susu yang diberikan penambahan bubur buah naga merah. Warna permen karamel susu perlakuan tanpa penambahan bubur buah naga merah atau kontrol yaitu berwarna coklat yang dihasilkan dari reaksi karamelisasi dan reaksi Maillard.

\section{Aroma}

Hasil uji organoleptik terhadap aroma permen karamel susu dapat dilihat pada Gambar 7.

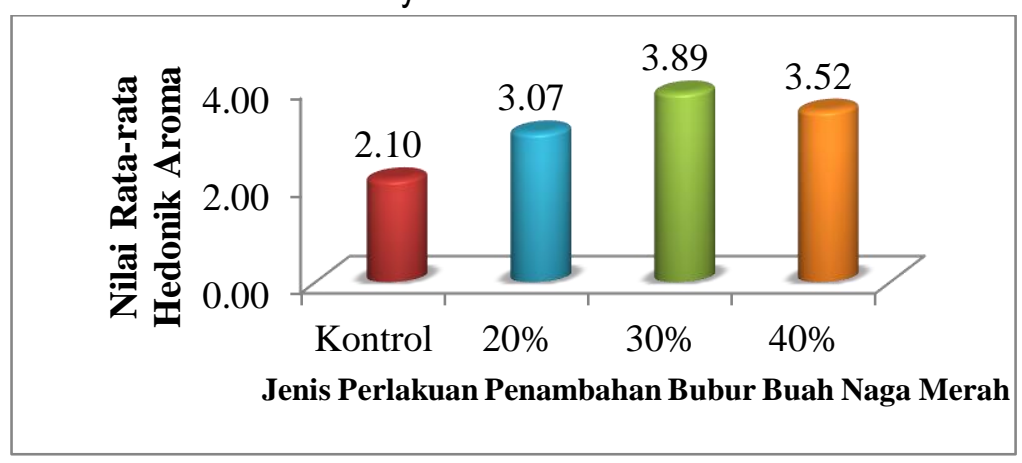

Gambar 7. Hasil uji hedonik aroma karamel susu

Analisis data menujukkan bahwa penambahan bubur buah naga merah memberikan pengaruh terhadap aroma permen karamel susu. Aroma permen karamel susu perlakuan kontrol dan penambahan bubur buah naga merah $20 \%$, $30 \%$, dan $40 \%$ memiliki perbedaan nyata. Pengujian hedonik aroma permen karamel susu menunjukkan permen karamel susu yang banyak disukai panelis diperoleh dari perlakuan penambahan bubur buah naga merah $30 \%$, aroma yang dihasilkan yaitu aroma yang baik, yang berasal dari perpaduan aroma susu dan aroma buah naga merah yang khas (aroma fruity dan sweet). 
Permen karamel susu dengan aroma yang kurang disukai panelis diperoleh dari perlakuan tanpa adanya penambahan bubur buah naga merah. Aroma yang dihasilkan hanya dipengaruhi oleh adanya proses karamelisasi dan reaksi Maillard yang menghasilkan aroma khas yaitu aroma karamel. Aroma dapat menentukan kelezatan suatu produk, seseorang dapat menilai lezat tidaknya suatu produk dari aroma yang ditimbulkan. Pengujian terhadap aroma produk sangat penting karena dapat dengan cepat memberikan hasil penerimaan terhadap produk yang diujikan diterima atau ditolak produk tersebut dan dapat juga sebagai indicator terjadinya kerusakan pada produk. Selain itu, melalui aroma kita dapat mengetahui bahan-bahan yang terkandung di dalam produk, Aroma bahan makanan banyak menentukan kelezatan makanan tersebut. Industri makanan menganggap sangat penting melakukan uji aroma karena dengan cepat dapat memberikan hasil penilaian produksinya disukai atau tidak disukai (Tobri, 2006).

\section{Rasa}

Hasil uji organoleptik dapat dilihat pada Gambar 8.

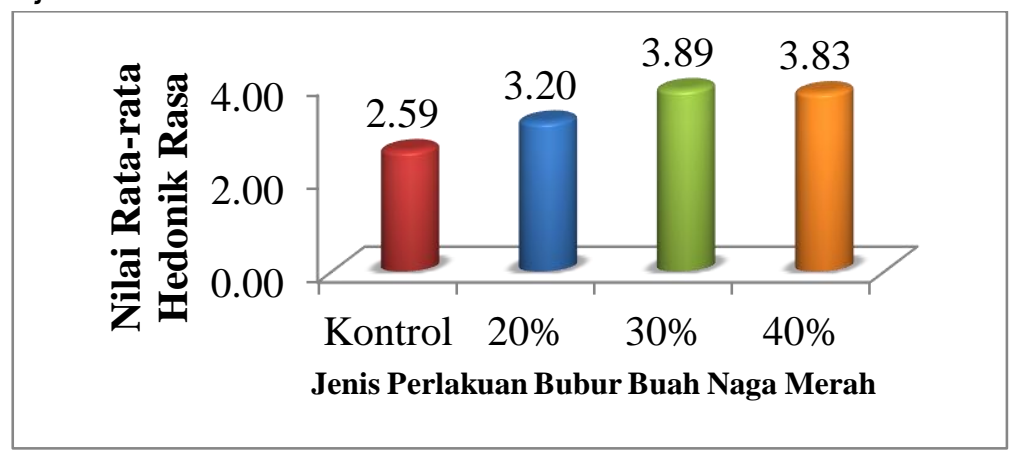

Gambar 8. Hasil uji hedonik rasa karamel susu

Penambahan bubur buah naga merah pada permen karamel susu memberikan pengaruh terhadap rasa permen karamel susu yang dihasilkan. Permen karamel susu perlakuan penambahan bubur buah naga merah $20 \%$, $30 \%$, dan $40 \%$ dengan permen karamel susu tanpa penambahan bubur buah naga merah atau kontrol menunjukkan perbedaan nyata.

Rasa permen karamel susu yang disukai panelis diperoleh dari perlakuan penambahan bubur buah naga merah $30 \%$ dan $40 \%$, rasa permen kedua perlakuan ini lebih manis dari permen karamel susu tanpa penambahan bubur buah naga merah atau kontrol. Hal ini sangat dipengaruhi oleh kadar gula reduksi yang dihasilkan. Kadar gula reduksi permen karamel susu perlakuan penambahan bubur buah naga merah $30 \%$ dan $40 \%$ lebih tinggi dibandingkan kadar gula reduksi permen karamel susu perlakuan lain. Semakin tinggi gula reduksi yang terkandung dalam permen karamel susu maka rasa yang dihasilkan akan semakin manis. Menurut Wahyuni (2011) buah naga merah mengandung monosakarida seperti glukosa dan fruktosa, dan selama proses pematangan kandungan pati dalam buahbuahan berubah menjadi gula-gula pereduksi yang akan menimbulkan rasa manis, buah naga merah sendiri mengandung kandungan gula sebanyak 13- 
$18^{\circ}$ Briks. Rasa permen karamel susu yang berada pada kisaran agak suka diperoleh dari perlakuan kontrol dan penambahan $20 \%$ bubur buah naga merah, rasa yang dihasilkan yaitu rasa karamel yang dipengaruhi oleh adanya proses karamelisasi sehingga rasa karamel yang lebih mendominasi.

\section{Tekstur}

Hasil uji organoleptik tekstur permen karamel susu yang dihasilkan dapat dilihat pada Gambar 9.

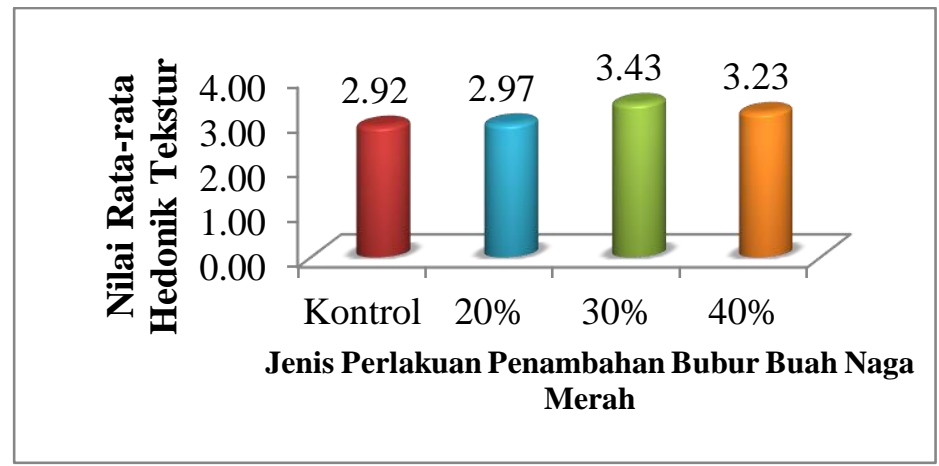

Gambar 9. Hasil uji hedonik tekstur karamel susu

Pengujian hedonik tekstur permen karamel susu menunjukkan hasil bahwa penambahan bubur buah naga merah memberikan pengaruh terhadap tekstur permen karamel susu yang dihasilkan. Hasil uji Duncan tekstur permen karamel susu menunjukkan bahwa permen karamel susu perlakuan penambahan $20 \%, 30 \%$, dan $40 \%$ bubur buah naga merah berbeda nyata dengan permen karamel susu tanpa penambahan bubur buah naga merah atau kontrol. Tekstur yang dihasilkan kenyal dan lembut, hal ini dikarenakan kadar air permen karamel susu perlakuan penambahan bubur buah naga merah tidak terlalu tinggi dan juga tidak terlalu rendah sehingga tesktur permen yang dihasilkan sesuai dengan tekstur permen karamel susu pada umumnya.

Tekstur permen karamel susu yang tidak disukai panelis diperoleh dari perlakuan tanpa penambahan bubur buah naga merah atau kontrol. Hal ini disebabkan oleh rendahnya kadar air permen yang dihasilkan sehingga tekstur permen yang dihasilkan menjadi keras dibandingkan dengan permen dengan penambahan bubur buah naga merah.

Menurut Euis (2007) nilai tekstur (keempukan atau kekerasan) berhubungan dengan kadar air yang terkandung di dalam permen. Afriandi, dkk (2018) menambahkan bahwa kadar air bahan tinggi dapat menyebabkan tekstur lembek pada permen karamel susu tetapi apabila kadar air bahan rendah dapat menyebabkan tekstur permen karamel susu menjadi keras.

\section{KESIMPULAN}

Simpulan yang dapat diperoleh dari hasil penelitian adalah sebagai berikut:

1. Hasil uji kimia permen karamel susu menunjukkan bahwa perlakuan penambahan bubur buah naga memberikan pengaruh terhadap kadar air, kadar abu, serat, gula reduksi dan antioksidan. Permen karamel susu terbaik dipeoleh dari perlakuan penambahan bubur buah naga merah 40\% dengan karakteristik kadar air $(3,54 \%)$, kadar abu $(1,98 \%)$, kadar serat 
$(1,48 \%)$, kadar gula reduksi $(2,18 \%)$, dan kadar antioksidan $(53,77 \%)$

2. Hasil uji hedonik permen karamel susu menunjukkan bahwa perlakuan penambahan bubur buah naga merah memberi pengaruh terhadap warna, aroma, rasa dan tekstur. Pemen karamel susu terbaik diperoleh dari perlakuan penambahan bubur buah naga merah $40 \%$ dengan karakteristik warna (4.10), aroma $(3,52)$, rasa $(3,83)$, dan rekstur $(3,23)$

\section{DAFTAR PUSTAKA}

Afriandi., Lahming, dan Subari Yanto. 2018. Pemanfaatan Limbah Kulit Pisang Kapok (Musa Paradisiacal Inn) dengan Variasi Buah Naga Menjadi Permen fungsional. Jurnal Pendidikan Teknologi Pertanian, Vol. 4 (2018) : 119-125 . Fakultas teknik Universitas Negeri Makassar

Budiyanto, A. 2002. Dasar-Dasar Gizi. Jakarta : Gramedia.

Budiyanto, M.A.K. 2002. Dasar- Dasar IImu Gizi. UMM Press: Malang.

Handayani Euis. 2007. Pembuatan karamel dari Susu Sapi (Kemasan) dan Karakteristik Fisik Serta Phnya.

Hardita Putri Anindya. 2015. Pengaruh Rasio Daging dan Kulit Buah Naga Merah (Hylocereus polyrhizus) Terhadap Karakteristik Selai. IImu dan Teknologi Pangan, Fakultas Teknologi Pertanian Universitas Udayana.

Paranoan, C., A,C., Lahming, dan Kadirman. 2017. Optimalisasi Konsentrasi Asam Tartrat dan Waktu Ekstraksi pada Ekstraksi
Pigmen Betasianin dari Kulit Buah Naga Merah (Hylocereus Polyrhizus) Sebagai Pewarna Alami. Jurnal Pedidikan Teknologi Pertanian, Vol. 3 (2017) : S126S133. FT.UNM

Sriwahyuni., M. Rais, dan Ratnawaty Fadilah. 2017. Fortifikasi Tepung Kulit Melinjo sebagai Pewarna Alami pada Pembuatan Kerupuk Singkong. Jurnal Pendidikan Teknologi Pertanian, Vol. 3 (2017) : 212-222. FT. UNM

Sumardana, G., Husain Syam, Dan Andi Sukainah. 2017. Subtitusi Tepung Bonggol Pisang pada Mie Basah dengan Penambahan Kulit Buah Naga Merah (Hylocereus Undatus). Jurnal Pendidikan Teknologi Pertanian, Vo. 3 (2017): S145-S157 .Ft.Unm

Tobri, M. 2006. Kualitas Fisik dan Organoleptik Daging Ayam Broiler yang Ransumnya diberi Penambahan Minyak Ikan yang mengandung Omega-3. Skripsi tidak diterbitkan. Bogor: Program Studi Teknologi Hasil Ternak Fakultas Peternakan Institut Pertanian Bogor. Http://depository.ipb.ac.id.

Wahyuni, rekna . 2011 . pemanfaatan kulit buah naga merah (Hylocereus polyrhizus) sebagai sumber antioksidan dan pewarna alami pada pembuatan jelly. Pasuruan: fakultas pertanian universitas yudharta. Jurnal teknologi pangan 
Winarno,F.G. 2004. Kimia dan Pangan. Jakarta: PT. Gramedia Pustaka Utama. 